\title{
Foundation for transdisciplinary education at Cape Peninsula University of Technology
}

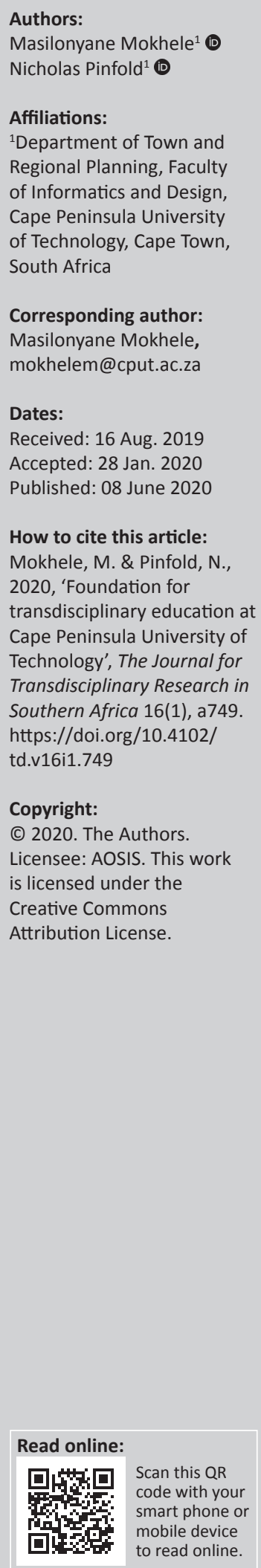

South Africa faces a multitude of social, economic and environmental challenges, which require well-considered planning efforts. However, the efficacy of the built environment professions to adequately plan for the current and future populations can to some extent be questioned. Factors that are arguably responsible for the failure of the professions to achieve the desired outcomes include the following: (1) the inability of professionals to comprehensively analyse community problems and (2) although the various professions might work on the same issues, they largely fail to transcend disciplinary boundaries. This state of affairs can in part be linked to the role of higher education, which is in a good position to equip future professionals with the skills required for the analysis of diverse societal problems. In spite of the importance of education and training, there is a paucity of literature that explore ways in which the South African higher education sector instils transdisciplinary thinking and, accordingly, imparts the requisite soft skills to students. Using the case study of Cape Peninsula University of Technology in Cape Town, the aim of this article was to present efforts that are pursued towards instilling transdisciplinarity in students. The efforts revolve around community service-learning pedagogy, which grants students a platform to work in close collaboration with communities. In the process, students and community members develop an in-depth understanding of the community's problems and how they could be collectively resolved.

Keywords: built environment; Cape Peninsula University of Technology; community service-learning; transdisciplinarity; planning education; qualitative GIS.

\section{Introduction}

South Africa is characterised by a myriad of social, economic and environmental challenges, which include, inter alia, high levels of unemployment, persistent inequality and the apartheid legacy of spatial segregation. Such problems particularly require the built environment and allied professionals $^{1}$ to be well equipped to deal with, among others, complexity, diversity and uncertainty. However, the efficacy of the aforesaid professions to successfully cater to the existing and future populations can, to some extent, be questioned. Factors that could arguably be a stumbling block to the achievement of the desired social, economic and environmental outcomes include the following: (1) limited understanding of the nuances of pertinent societal issues (National Planning Commission 2012) and relatedly (2) although the various professions might work on the same issue, they largely work in silos and fail to transcend disciplinary boundaries. It is nonetheless important to acknowledge that the possible reasons for the relative ineffectiveness of the built environment and allied professions are complex and multifaceted, and the blame cannot be put solely on the professions concerned (see Duminy, Odendaal \& Watson 2014, with specific reference to urban and regional planning).

The inability to achieve the intended objectives can, in part, be linked to the role of the higher education sector, which is entrusted with the responsibility of training professionals who can tackle multifaceted societal problems head-on. It therefore stands to reason that the sector is in a good position to equip future professionals with the skills required to analyse and appreciate the multidimensional societal problems. Relatedly, the higher education sector is expected to train students in ways that instil collaborative thinking and practice. With specific reference to urban and regional planning, Duminy et al. (2014) advance critical imperatives that could be addressed towards making planning more effective. Relating primarily to the need for data, relevant skills and ethical awareness among the graduates, the imperatives include the following: (1) the production of accurate data to assist the planning process and (2) the development of relevant professional skills and competencies. In this regard, educational approaches need to groom 1.The built environment and allied professions include, among others, urban and regional planning, engineering, construction management, architecture and quantity surveying. 
planners who are innovative problem-solvers, capable of collaborating with various actors involved in the development process, particularly the communities (Duminy et al. 2014).

In spite of the undeniable importance of education and training, there is limited literature on ways in which the South African higher education sector instils transdisciplinarity, and accordingly imparts the requisite soft skills to students. This gap particularly exists in the context of the built environment and allied disciplines. Using a case study of the Cape Peninsula University of Technology (CPUT) in Cape Town, South Africa, the aim of this article is to, at least in part, contribute towards filling that gap by presenting efforts that are currently undertaken to instil transdisciplinarity in students. As discussed herein, the efforts presented are not claimed to be the so-called best practice but are merely the beginning of a journey towards transdisciplinary teaching and learning. The article is specifically centred on community service-learning (henceforth used interchangeably with service-learning) as a vehicle for transdisciplinary education.

Transdisciplinarity is becoming a catchword that is increasingly difficult to define, constituting what Nicolescu (2010) refers to as a war of definitions. Given that they are often conflated, the concept of transdisciplinarity needs to be explored in contradistinction to the related concepts of disciplinary collaboration (Gehlert et al. 2010), namely, interdisciplinarity and multidisciplinarity. Multidisciplinarity entails the combination of insights from a number of disciplines towards resolving a particular problem or answering a given question. This approach brings together the insights of different disciplines without attempting to integrate them (Leavy 2011; Repko 2008; Wall \& Shankar 2008). In interdisciplinarity, there is notably reliance on individual disciplines for their theories, concepts and methods towards understanding a particular problem. The methods are thus transferred from one discipline to another, although the ultimate process remains grounded in the framework of one discipline (Leavy 2011; Repko 2008).

Hadorn et al. (2008) reiterate that transdisciplinarity is ambiguous and is informed by different lines of thought. To add to the confusion of definition, there is no consistency in the literature in terms of when the concept was coined. It is typically recorded that transdisciplinarity can be traced to the first international conference on interdisciplinarity held in 1970 in France (see Hoffman-Riem et al. 2008; Klein 2008). On the contrary, some commentators argue that the concept first appeared in the 1980s (see Gehlert et al. 2010). It should also be noted that transdisciplinarity takes varying directions in different contexts and countries (Du Plessis, Sehume \& Martin 2014; Van Breda \& Swilling 2018). In transdisciplinarity, members of different disciplines work together to contribute towards concepts (and even theories) and methods that integrate and transcend the perspectives of individual disciplines (Stokols et al. 2010; Wall \& Shankar 2008). In that process, crossfertilisation of knowledge and skills occurs (Du Plessis et al. 2014). In a transdisciplinary approach, educators, professionals and/or researchers develop shared frameworks that extend discipline-specific theories, concepts and methods towards creating a new language to address a given situation or problem (Stokols et al. 2010). As it could be argued with the other forms of disciplinary collaboration, the notion of transdisciplinarity acknowledges the complexity, interconnectedness and multidimensionality of reality; hence, it makes a call for the use of more than one discipline towards exploring reality (Du Plessis et al. 2014; Martin 2017). Transdisciplinarity is particularly important when the knowledge about a certain situation is uncertain and when the origin and nature of the problem is disputed (Hadorn et al. 2008).

Although there is no consensus in the literature, the distinguishing characteristics of transdisciplinarity from the associated concepts are: (1) it integrates the disciplines with non-academic actors (see Palmer, Owens \& Sparks 2006). However, certain sections of the literature argue that multidisciplinarity also incorporates non-academic actors (e.g. see Frodeman 2010). Nonetheless, transdisciplinarity intends to close the gap between, on the one hand, research and education, and on the other hand, knowledge that is required towards solving societal problems (Hoffman-Riem et al. 2008). (2) In transdisciplinarity, as noted above, the theoretical, conceptual or methodological standpoints are not only taken from one discipline and applied to other disciplines, but rather transcend the disciplines and are thus applicable to numerous fields (Repko 2008). Notwithstanding these subtle differences, Nicolescu (2010) maintains that transdisciplinarity, interdisciplinarity and multidisciplinarity complement each other and should thus not be regarded as being in opposition. Needless to say, all these approaches are anti a situation where only one discipline is involved towards addressing a particular problem, which could be termed monodisciplinarity (seeGehlert et al.2010) or unidisciplinarity (see Stokols et al. 2010).

Typically occurring in the context of community-university partnerships, community service-learning affords students an opportunity to work with communities on projects. It familiarises students with socially contingent modes of knowledge generation (Elwood 2004). Scholars in various disciplines believe that community service-learning contextualises knowledge production by giving students an opportunity to become familiar with society's problems (Conner \& Erikson 2017; Hall 2010; Petersen \& Osman 2017; Pinfold 2014a; Thomson et al. 2011).

The South African higher education system requires that Higher Education Institutions (HEIs) incorporate community engagement as one of the pillars alongside teaching and learning, and research (Hall 2010). However, progress in implementing community engagement in South African HEIs has been rather slow and arguably confused because of, among others, a lack of conceptual clarity. In fact, community service-learning at times receives a somewhat negative reaction across a range of HEIs in South Africa (Mouton \& Wildschut 2007). Hall (2010:6) suggested that the resistance to community engagement and community service-learning is 'an epistemological disjuncture in the way knowledge is 
structured and organised'. Liu (1995) believes that community service-learning will continue to be questioned so long as an alternative pedagogy without an explanation of its underlying epistemology. Liu (1995) is of the view that community service-learning should be centred in the epistemology of pragmatism, which is typically characterised by a positive attitude towards integrating practice. Adopting a pragmatic epistemological framework has important pedagogical implications for teaching and learning. In response to Liu's view, some service-learning advocates concur that community service-learning pedagogy should be grounded in a specific epistemology, although they question the appropriateness of pragmatism (Richman 1996; Yoder 2016). Others argue that community service-learning does not need a discrete epistemology (Tucker 1999). Mitchell (2008) contrasted the traditional approach to community service-learning with the critical approach. The traditional approach is seen as apolitical and involves individual change during student development, whereas a critical approach aligns student outcome with social change. Critical community service-learning is aimed at addressing injustice by taking a political approach when pursuing social justice. This progressive way of teaching requires educators to focus on society at large as well as on critical issues (Mitchell 2008).

\section{Overview of literature on transdisciplinary education}

Before discussing the community service-learning initiative, which is the subject of this article, it is pertinent to provide a snapshot of the literature on transdisciplinary education. Although they are not easy to isolate, the overview focusses specifically on transdisciplinary education as opposed to transdisciplinary research. Furthermore, the discussion focusses on HEIs as opposed to schools (e.g. Woest 2018).

As with the ambiguity regarding the definition of transdisciplinarity relative to the associated concepts, Nash (2008) notes that the distinction between transdisciplinary training and other integrative training approaches is not clear-cut. It is often understood that in multidisciplinary training, students are taught the approach of a given discipline, while they also become familiar, and learn to work, with other disciplines. In interdisciplinary training, the intention is to groom professionals who possess knowledge of varying concepts, theories and methodological skills. In this way, transdisciplinary training aims to groom professionals who are able to synthesise the conceptual, methodological and/or theoretical aspects of various disciplines (Aneas 2015; Nash 2008).

It stands to reason that there is a wide gap between the environment where students are trained and the contexts they are expected to work within upon qualifying. At university, training is typically geared towards disciplinespecific qualifications under the guidance of mentors in given disciplines, although the students are ultimately required to understand and solve transdisciplinary problems
(McClam \& Flores-Scott 2012; McDaniels \& Skogsberg 2017). To fill that gap, Klein (2008:406) makes a call for 'disciplinary depth, multidisciplinary breadth, interdisciplinary integration and transdisciplinary competencies'.

There are various approaches to transdisciplinary education that are advanced in the literature, while acknowledging that individual disciplines do not necessarily vanish (see the case of CPUT presented herein). The following approaches (which are also relevant to other modes of integrative training) can be highlighted: firstly, it is typically recommended that students enrol in courses or subjects in a wide range of disciplines, while developing a solid background in one (Bradbeer 1999; Klein 2008). Secondly, students are encouraged to undertake projects, theses or dissertations under the supervision of staff from different disciplines (Klein 2008; Wall \& Shankar 2008). Thirdly, and related to the above, novice investigators are encouraged to conduct research projects at a centre or department other than their own over a certain period. In the process, investigators collaborate on joint projects with colleagues in other institutions (Stokols et al. 2010) or departments. Fourthly, universities are encouraged to develop curricula that are aligned towards transdisciplinarity (Eishof 2003; Klein 2008).

It cannot be claimed that the list of approaches above is exhaustive, and Stokols et al. (2010) note that with the growing interest, transdisciplinary training approaches are likely to grow. Fischer and Derry (2005) cited in Klein (2008) proposed the following transdisciplinary competencies, which, though are intended for science, technology, engineering and mathematics, could be widely applicable: (1) the ability to participate in communities and communicate effectively, as was performed in the Goedverwacht servicelearning project discussed herein; (2) Possession of metacognitive skills, including critical thinking skills that enable lifelong learning and self-directed learning; (3) the ability to understand, develop and operate in innovative socio-technical environments; (4) the ability to develop and guide knowledge building, and understand communities as contexts of teaching and learning; and (5) concern about realworld needs and willingness to be engaged citizens (Derry \& Fischer 2005 cited in Klein 2008).

McDaniels and Skogsberg (2017) add that the requisite competencies are at the cognitive, interpersonal and intrapersonal levels. These competencies would enable the students to perform in transdisciplinary contexts by being able to engage with diverse professionals (Polkinghorne 2004 cited in McDaniels \& Skogsberg 2017) and communities.

Obstacles to transdisciplinary education (and the associated modes of disciplinary collaboration) that are highlighted in the literature include the following: (1) challenges emerge when there is a clash between the natural learning of the students and the approaches used in various disciplines. (2) The learning of the values, culture, language and so on of various disciplines can be confusing and frustrating to students. (3) Students have to learn to operate in the 
ambiguous environment between the disciplines, which is an unknown space that is overseen by the educator, who might also feel lost. (4) It can be frustrating for the students to engage with unfamiliar community members and counterparts from other disciplines. (5) The engagement in various disciplines can result in a fear of loss of disciplinary identity (Bradbeer 1999; Nash 2008).

\section{Cape Peninsula University of Technology's attempts at transdisciplinary community service-learning}

In light of the overview of concepts and literature presented above, thissection delineates attempts towards transdisciplinary education at CPUT's Department of Town and Regional Planning. It is important to note that the efforts presented herein were not strictly designed according to the prescripts of transdisciplinary training projects. Similarly, the initiatives were not designed as research projects but were merely conceived as ways of training students through community engagement. Community engagement at CPUT involves collaboration with individuals, groups and organisations, outside of CPUT, wherein particular economic and social objectives are pursued. Engaged teaching and learning initiatives, volunteerism, research, cooperative education and community service-learning are employed in these interactions (Scheepers 2014). In spite of community service-learning being practised in a number of departments at CPUT, a gap exists in the way academics perceive service-learning and how they integrate it into the curricula. In the Department of Town and Regional Planning, community service-learning projects are thus far integrated into selected first-, second- and third-year subjects of the National Diploma in Town and Regional Planning and Diploma in Urban and Regional Planning.

It should be noted that currently, although the academic structure of CPUT allows students to enrol in subjects across academic departments, and even across faculties, such crossfertilisation is not a common practice, and it is not promoted in earnest. This apparent lack of coordination creates a barrier to the implementation of various approaches to transdisciplinary education advanced by, among others, Klein (2008). This is with particular reference to a call for students to enrol in subjects in various disciplines (refer to the Overview of Literature on Transdisciplinary Education section).

As a point of entry into community service-learning, in 2010, the Department of Town and Regional Planning released five students to participate in the Violence Prevention through Urban Upgrading (VPUU) programme in Khayelitsha, Cape Town. Violence Prevention through Urban Upgrading aims to develop safe, integrated and sustainable communities through area-based community development programmes. It is a partnership between the City of Cape Town municipality, international agencies and non-governmental organisations. Notably, there was no written partnership agreement between the department, the community and other organisations involved in the project, so the participation of students was essentially voluntary. Unfortunately, the apparent lack of support from other stakeholders (and confusion on the role of the university) resulted in the students becoming despondent and finally withdrawing from the project (Pinfold 2014a). As a result of this failed initiative, the department took a stern position that it would no longer participate in volunteerism but would focus on building sustainable community engagement partnerships.

In 2012, the Department of Town and Regional Planning participated in the Flamingo Crescent informal settlement upgrade in Lansdowne, Cape Town (see Pinfold 2014b), which was used as a baseline for implementing other community service-learning projects in the department. Students and staff assisted with the coordination of a map compiled by the residents of Flamingo Crescent in anticipation of a re-blocking process. ${ }^{2}$ In line with the argument raised by Bringle et al. (2004), the engagement developed education around learning outcomes and community partnerships that broadened the students' disciplinary knowledge and a sense of civic responsibility.

Since 2014, the department has been involved in the Goedverwacht Moravian Mission Station community service-learning project, and also commenced work on St Mark's Church (District Six) baptismal records mapping project in 2018. The two projects integrate students and academic staff of different departments (across faculties) at CPUT. At some stage, the St Mark's Church project also included students (enrolled in diverse courses) from the University of Michigan, USA. Goedverwacht and St Mark's projects are at least in part transdisciplinary in their approach given that a shared conceptual framework (which draws on the concepts and approaches of various disciplines) is used to analyse community dynamics. Prefaced with a note on ethics, the Goedverwacht Moravian Mission Station project is presented hereunder.

\section{Ethical consideration}

This article followed all ethical standards for a research. Service-learning activities at CPUT are administered through the policy and procedures for community engagement. If departments pursue research-specific community engagement activities, then formal ethical clearance approval is needed. As mentioned before, Goedverwacht Mission Station initiative was not designed as a research project. As such, no research proposal was submitted to CPUT for ethical clearance. It should nonetheless be noted that the initiative was scrutinised by the relevant units of CPUT, and ultimately registered by the university as a service-learning project. The registration was followed by the signing of a memorandum of agreement by the various stakeholders. In light of a grey area on what constitutes 'ethical clearance' in this regard, the presentation below does not include details that may raise

2.Re-blocking is an in-situ upgrade of an informal settlement where existing structures are reorganised in a more structured way so that, among others, basic services can be provided (City of Cape Town 2013). 


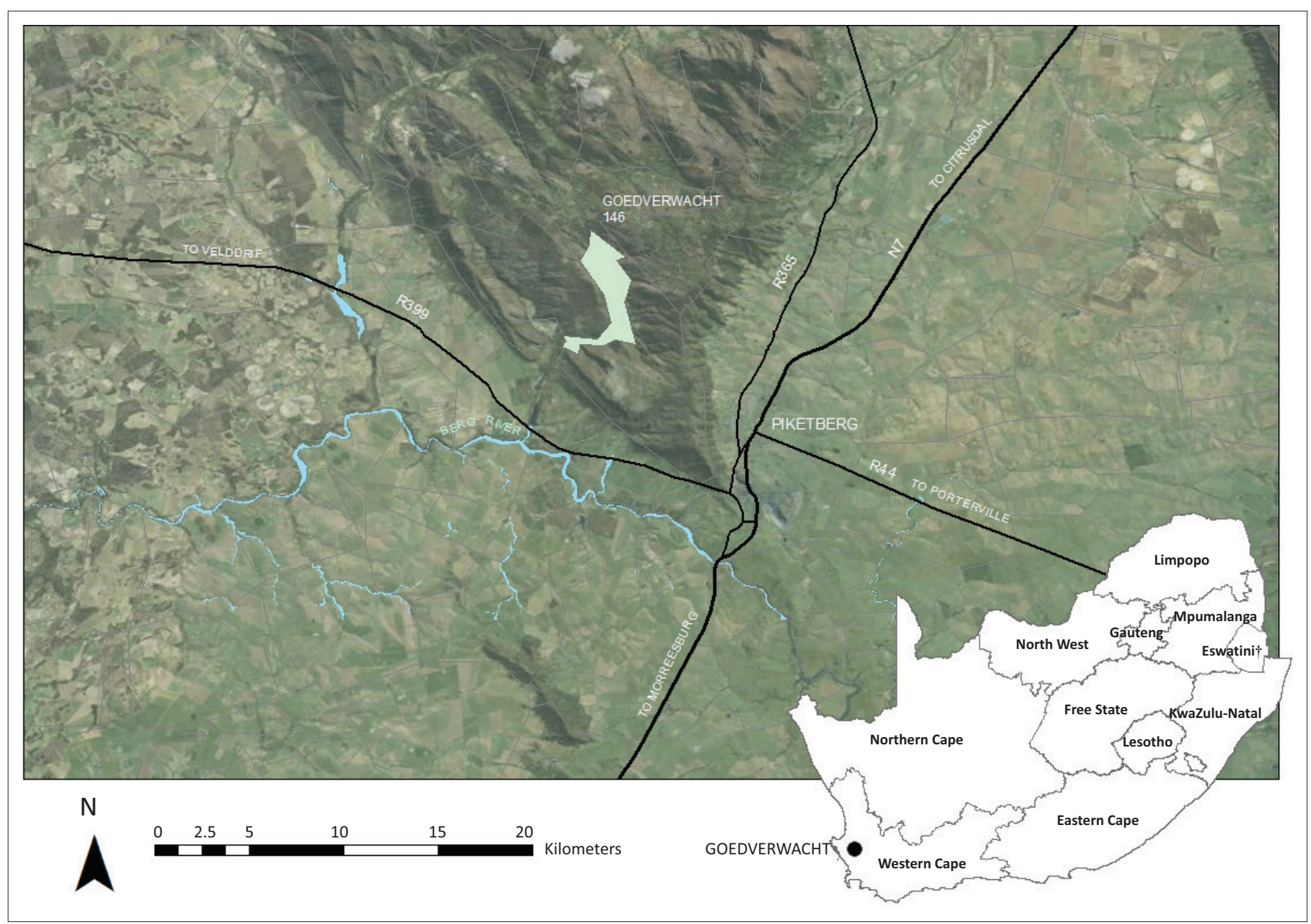

Source: Adapted from Pinfold, N., 2018, 'Communicative mapping as a means for promoting legal land tenure: The case study of the Goedverwacht Moravian Mission Village, in the Western Cape, South Africa', Town and Regional Planning 72, 1-12. https://doi.org/10.18820/2415-0495/trp72i1.1

$\dagger$, Formerly known as Swaziland.

FIGURE 1: Location of Goedverwacht Moravian Mission station.

ethical questions, namely, names of community members, student names, photographs or any work that emanated from the project. The narrative merely reports on the teaching and learning methods used and processes followed.

\section{Goedverwacht Moravian Mission Station community service-learning project}

Established in 1889, Goedverwacht Moravian Mission Station is a communal village located in Bergriver local municipality, approximately $150 \mathrm{~km}$ north of Cape Town, in the Western Cape province (Figure 1). ${ }^{3}$ Consisting of about 500 households, this picturesque settlement is characterised by gardens of fertile soil along the Platkloof River, with homesteads situated on the upper sides of the valley. The residents of Goedverwacht do not hold individual title deeds to their residential plots. Rather, the mission station is under the trusteeship of the Minister of Rural Development and Land Reform in accordance with the Rural Areas Act, No. 9 of 1987 (Republic of South Africa [RSA] 1987). This

\footnotetext{
3.Mission towns were established in South Africa to provide housing for the marginalised in society where they could live under the guidance of the church In the Western Cape province, mission stations provided a sheltered existence to In the Western Cape province, mission stations provided a sheltered existence to
people who were mainly former slaves and Khoisan pastoralists deprived of their people who were main
land (Fransen 2006)
}

arrangement implies that Goedverwacht does not fall in the jurisdiction of Bergriver local municipality, which is consequently not legally responsible for development and specifically the provision of services in the area. However, the newly enacted Western Cape Land Use Planning Act [LUPA], 2014 (Province of the Western Cape, 2014), which repealed the Rural Areas Act, 1987 (RSA 1987), requires that all land within a municipal boundary, which is not regulated by a zoning scheme or town planning scheme, be incorporated into an existing scheme as contemplated in section 33(1) of the Act. This implies that Goedverwacht Moravian Mission Station would ultimately fall under the jurisdiction of the local municipality, and possibly cease to be a communal village.

An official of the Bergriver local municipality approached CPUT's service-learning unit, requesting the university to assist the community of Goedverwacht Moravian Mission Station with planning-related matters. The community required assistance particularly because the Bergriver municipal spatial development framework did not have concrete development proposals pertaining to Goedverwacht. This was the case because, as noted above, Goedverwacht is not under the jurisdiction of the municipality. At the time, the 
expectation was that CPUT would, among others, prepare a plan (i.e. spatial development framework) for the settlement. The service-learning unit then asked the Department of Town and Regional Planning and other departments at CPUT to step in and lend a helping hand.

The Goedverwacht project was thus envisaged to be an interdisciplinary initiative involving multiple faculties and departments. The intention was that the project would encourage a partnership between departments to explore issues and integrate disciplinary perspectives. It became evident that a transdisciplinary approach was emerging, which combined community's wisdom with students' elementary knowledge. Engagement with non-academic communities requires breaking down of disciplinary boundaries to address the fragmented manner in which students favour their disciplines rather than learning beyond the university curricula. The community also developed a sense that they had control over the outcomes and processes followed by students. It is hoped that the project will have a long-term impact for the community, such as awareness of public policy, land reform and access to community services. The underlying core value of the project is social justice.

The Goedverwacht community service-learning project was inaugurated in July 2014, with a meeting between Bergrivier local municipality, Goedverwacht community (represented by the church) and a group of service-learning coordinators from various departments at CPUT. An official of the Bergrivier municipality, who grew up on the Goedverwacht Mission Station, arranged that meeting. Instead of convening a community meeting, it was understood that the church leadership would subsequently apprise the community of CPUT's anticipated role in the community.

One of the crucial elements of community-university partnerships is a carefully crafted and co-signed agreement, which specifies activities to be conducted (see Ball 2014). For the Goedverwacht project, the service-learning cooperation was signed in 2014 between CPUT (the service-learning unit, town and regional planning, and construction management and quantity surveying departments) and the Goedverwacht Moravian Mission Station (represented by the Moravian Church). Notably, because of the unforeseen circumstances, notwithstanding their crucial role in kick-starting the initiative, Bergrivier municipality did not sign the agreement. The agreement specified the undertaking of the aforementioned parties, which cannot be disclosed herein because of a confidentiality clause that was agreed upon. Nonetheless, it should be noted that in the line of the argument raised by Ball (2014), the Goedverwacht Moravian Mission Station community was made aware that they would participate in the project without expecting instant (tangible) benefits. All in all, the partnership intended to promote a holistic and collaborative approach, which encouraged the participation of Goedverwacht community, and had as its central focus the notion that the community shall determine its own development agenda.

Following preliminary conversations with the community, it was confirmed that Goedverwacht Mission Station had no cadastral boundaries, which is a characteristic that acted as a stumbling block to development, particularly the installation of bulk infrastructural services (water, sewer, storm water and electricity). Relatedly, it was also discovered that the community did not have a basic map that showed, among others, a layout of the settlement. Given these revelations, and in consultation with the community, it was established that the immediate need was to compile a map towards determining the cadastral boundaries. Notably, the immediate focus was no longer the preparation of a spatial development framework per the original expectation.

A conventional way of addressing the problem of cadastral boundaries would be for the experts to use topographical maps and aerial photographs of the settlement (supplemented with other secondary material and site visits) to decide on the logical property boundaries that comply with the technical and legal requirements for formal land registration. However, as elaborated below, instead of the said technical exercise, the Department of Town and Regional Planning opted for what is arguably a transdisciplinary approach that involved community members and students enrolled in various courses. This approach had characteristics of qualitative geographic information system (GIS), which incorporated various forms of knowledge, new practices and knowledge production through reflexive methods (Elwood \& Cope 2009).

In accordance with the service-learning agreement, the Goedverwacht Mission Station initiative involved students and academic staff from the faculties of informatics and design (Department of Town and Regional Planning), and engineering and built environment (Department of Construction Management and Quantity Surveying). Under the supervision of academic staff, students collaborated with community members to better understand the status quo and collectively develop recommendations towards establishing cadastral boundaries. As a starting point, the settlement was divided into precincts wherein each group of students had about 10 properties to work with in terms of measuring the boundaries and engaging with community members. Academic staff supervised the project and provided continuity with the community and students. Lecturers therefore disseminated information before engagement, provided support during engagement and facilitated reflection sessions. It should be noted that instead of developing selection criteria and determining a number of community participants, it was decided that members of the community would collaborate with the students as and when required, that is, whenever the students were in particular 'precincts'. In this way, all community members had a chance to participate.

Between 2014 and 2018, a total of 539 students participated in the initiative (see Table 1), with the project connected to the respective disciplinary coursework. On average, approximately 30 third-year students per year (completing their National Diploma in Town and Regional Planning) were conscripted into the project as part of their training in the subject 'Geographic Information Systems'. A total of 370 
TABLE 1: Number of students involved in the Goedverwacht project between 2014 and 2018.

\begin{tabular}{llc}
\hline Faculty & Department & Number of students \\
\hline Informatics and Design & Town and Regional Planning & 166 \\
$\begin{array}{l}\text { Engineering and Built } \\
\text { Environment }\end{array}$ & $\begin{array}{l}\text { Construction Management } \\
\text { and Quantity Surveying }\end{array}$ & 370 \\
Business & $\begin{array}{l}\text { Management and Project } \\
\text { Management }\end{array}$ & 3 \\
\hline Total & - & $\mathbf{5 3 9}$ \\
\hline
\end{tabular}

first-year students from the Department of Construction Management and Quantity Surveying in the Engineering and Built Environment Faculty participated over the years as part of the 'Site Surveying' subject (130 students in 2014, 220 in 2015 and 20 in 2018). Although the Business Faculty was not part of the memorandum of agreement, in 2018, three students from that faculty participated in the project as part of their second-year 'Project Management' subject in the National Diploma in Management.

Students from the various departments (as noted above) worked together on the project in groups varying in size from 12 to 24 members wherein only one group per week visited the community. Each group (including the academic staff) was bussed from CPUT's District Six and Bellville campuses to Goedverwacht Mission Station where they spent 1 day with the community. The average age of first-year students was 19 years, with most students beginning their tertiary education directly after high school.

Upon arrival at Goedverwacht, students would congregate at the village centre referred to as the werf, which is conceived as a public place consisting of communal buildings and linkages to and from the village. A part of the village werf, the old granary mill, now a museum, has historically been a place where people meet. The church and its bell tower dominate the mill. This place of peaceful quietude is where students and academic staff congregated before dispersing into the village along the avenue of trees, gravel pathways, picket fences and hedges. The werf precinct is of particular importance to the community and has been identified as a future restoration project by the community members and students.

With the input of community members, the project facilitated the gathering of geospatial information into a simple database and map, which can in the future be used by the community and other stakeholders for planning purposes. As noted earlier, the purpose of the mapping exercise was to establish cadastral boundaries at an accuracy that was not necessarily constrained by technical and legal requirements for formal land registration. Property boundaries were determined based on a combination of the knowledge of the residents, visible physical topographies captured using mobile GIS/global positioning systems (GPSs), smartphone data-gathering and application software, and aerial photography captured with a drone. The geographic data were stored in an ArcGIS computer program's geo-database where it could be readily accessed and updated by the students and/or staff. The intention was to ultimately equip and empower community representatives
TABLE 2: A summary of expectations before and after transdisciplinary collaboration.

\begin{tabular}{|c|c|c|}
\hline Participants & Expected contribution & Outcome \\
\hline $\begin{array}{l}\text { - Department of Town } \\
\text { and Regional Planning } \\
\text { - Department of } \\
\text { Construction Management } \\
\text { and Quantity Surveying } \\
\text { - Community of } \\
\text { Goedverwacht } \\
\text { Moravian Mission Station }\end{array}$ & $\begin{array}{l}\text { - Community profiling } \\
\text { and mapping } \\
\text { - Inventory of existing } \\
\text { infrastructure and } \\
\text { services } \\
\text { - Tacit knowledge } \\
\text { (e.g. the history } \\
\text { and dynamics of } \\
\text { the community) }\end{array}$ & $\begin{array}{l}\text { Engineering and urban } \\
\text { and regional planning } \\
\text { students collaborated } \\
\text { with the community } \\
\text { members. This process } \\
\text { replaced the traditional } \\
\text { (categorical) method of } \\
\text { data collection with a } \\
\text { more responsive and } \\
\text { context-sensitive } \\
\text { approach. }\end{array}$ \\
\hline
\end{tabular}

with elementary GIS skills so that they could view and update the database themselves as well as pass the skill to other community members.

During the aforesaid data collection process, students were exposed to a unique experience, which required a sense of responsibility towards the community. Reflective sessions before, during and after engagement provided a means to measure changes in the students' knowledge. It also granted the students time and space to critically reflect on their experience and understand the relevance of the project to their learning in the classroom. The main form of reflection was where students told stories (orally and pictorially) about their experience. During these sessions, students began to understand that impressions and ideas vary and that not everyone would necessarily have a positive feedback. Individual reflective essays were also presented, outlining what students had performed and what they intended to do in the future. The final submission was a portfolio, which included maps (compiled in GIS) accompanied by statistics, graphs and the associated analysis.

In summary, the mapping process taught the students communication, collaboration and mapping skills. Table 2 depicts how the monodisciplinary contribution was transformed into a richer outcome. This transdisciplinary, bottom-up approach to information collation was meant to provide an opportunity for the community to contribute towards developing their own solutions.

\section{Conclusion}

Given the apparent inability of the built environment and the allied disciplines to contribute meaningfully towards solving societal problems, it is believed that the higher education sector can play a significant role in grooming graduates who are able to tackle complex social, economic and environmental problems head-on. It stands to reason that transdisciplinarity is one of the skills that can be imparted in this regard. A number of approaches to transdisciplinary education are advanced in the literature, including a call for students to enrol in a variety of subjects that are beyond the ambit of one's discipline. The article extends the literature by reflecting on how community service-learning can be used as a vehicle for instilling transdisciplinary skills in students. The article does not claim that the work presented herein is best practice; instead, it is a reflective, retrospective account of engaging transdisciplinary studies with the intention of instilling transdisciplinarity in higher education curriculum. The primary aim of the 
Goedverwacht Mission Station community service-learning project was to produce a cadastral map of the settlement's property boundaries. It was intended that the map would prepare the community for land tenure reform through a community-driven land rights enquiry. The map also provided residents with a visual account of community assets. Students from different faculties and departments worked together and shared their disciplinary skills. Town planning students responded to community challenges with particular reference to the social, economic and natural resources. Their focus centred on community dynamics and community participation. Students from the Department of Construction Management and Quantity Surveying focussed more on the cost, procurement and management of construction projects and property development. Students and community members were collectively able to identify a shared vision of engagement and empowerment. This transdisciplinary learning approach allowed students to collectively unravel the social undercurrents of communal life and share disciplinary perspectives to achieve co-production of analytical and problem-solving skills.

In the post-apartheid era, South African HEIs are called upon to commit to community service-learning initiatives. Cape Peninsula University of Technology academics have accordingly embarked on service-learning pedagogy in an attempt to provide students with an in-depth appreciation of social, economic, environmental and physical problems and aspirations of communities. However, the academics question the value of service-learning pedagogy in providing a service (with immediate tangible benefits) to a community during engaged scholarship learning. Community service-learning projects at CPUT have provided evidence that servicelearning provides an opportunity for students to learn practical skills, while community members benefit from the awareness created. People who live in communal settlements have a direct and immediate interest in their space and identify with the place they live in. The general assumption is that the mapping provides an approach, which empowers community members to realise their own development potential. Knowledge production in this instance is socially constructed and mediated locally.

University-community engagement should not only be seen as an opportunity for students to learn by contributing towards solving problems in a community but should also provide a more reflective scholarly approach where students are exposed to deeper issues than merely preconceived problems. The complexity of societal undercurrents requires a transdisciplinary approach to community service-learning where cooperation between disciplines results in co-production of knowledge and shared outcomes. Co-constructed knowledge generated by university students and community partners provides perspectives that can be integrated to provide a holistic understanding of community dynamics. This project shows that community service-learning is flexible and can accommodate multiple disciplines and provide meaningful service to communities. The positive progress of the Goedverwacht community service-learning project at
CPUT indeed points to a pedagogy, which could encompass transdisciplinary learning to enrich scholarship and provide civic responsibility.

\section{Acknowledgements Competing interests}

The authors have declared that no competing interest exists.

\section{Authors' contributions}

All authors contributed equally to this work.

\section{Funding information}

This research received no specific grant from any funding agency in the public, commercial or not-for-profit sectors.

\section{Data availability statement}

Data sharing is not applicable to this article as no new data were created or analysed in this study.

\section{Disclaimer}

The views and opinions expressed in this article are those of the authors and do not necessarily reflect the official policy or position of any affiliated agency of the authors.

\section{References}

Aneas, A., 2015, 'Transdisciplinary technology education: A characterisation and same ideas for implementing in the university', Studies in Higher Education 40(9), 1715-1728. https://doi.org/10.1080/03075079.2014.899341

Ball, J., 2014, 'On thin ice: Managing risks in community-university research partnerships', in C. Etmanski, B.L. Hall \& T. Dawson (eds.), Learning and teaching community-based research: Linking pedagogy to practice, pp. 25-44, University of Toronto Press, Toronto.

Bradbeer, J., 1999, 'Barriers to interdisciplinarity: Disciplinary discourses and student learning', Journal of Geography in Higher Education 23(3), 381-396. https://doi. org/10.1080/03098269985326

Bringle, R.G., Phillips, M.A. \& Hudson, M., 2004, The measure of service-learning: Research scales to assess student experiences, American Psychological Association, Washington, DC

City of Cape Town, 2013, Proactive re-blocking of informal settlements (Policy Number 13282), viewed 01 August 2018, from https://resource.capetown.gov.za/ documentcentre/Documents/Bylaws $\% 20$ and $\% 20$ policies/Proactive $\% 20$ ReBlocking $\% 20$ of $\% 20$ Informal $\% 20$ Settlements $\% 20-\% 20$ (Policy $\% 20$ number $\% 20$ 13282)\%20approved $\% 20$ on $\% 2030 \% 200$ ctober $\% 202013$.pdf

Conner, J. \& Erickson, J., 2017, 'When does service-learning work? Contact theory and service-learning courses in higher education', Michigan Journal of Community Service Learning 23(2), 53-65. https://doi.org/10.3998/mjcsloa.3239521.0023.204

Duminy, J., Odendaal, N. \& Watson, V., 2014, 'The education and research imperatives of urban planning professionals in Africa', in S. Parnell \& E. Pieterse (eds.), Africa's urban revolution, pp. 184-199, UCT Press, Cape Town.

Du Plessis, H., Sehume, J. \& Martin, L., 2014, The concept and application of transdisciplinarity in intellectual discourse and research, Real African Publishers, Johannesburg.

Eishof, L., 2003, 'Technological education, interdisciplinarity, and the journey towards sustainable development: Nurturing new communities of practice', Canadian Journal of Science, Mathematics and Technology Education 3(2), 165-184. https://doi.org/10.1080/14926150309556558

Elwood, S. \& Cope, M., 2009, 'Introduction: Qualitative GIS: Forging mixed methods through representations, analytical innovations, and conceptual engagements', in M. Cope \& S. Elwood (eds.), Qualitative GIS: A mixed methods approach, pp. 1-12, Sage, London.

Elwood, S.A., 2004, 'Experiential learning, spatial practice, and critical urban geographies', The Journal of Geography 103(2), 55-63. https://doi.org/ 10.1080/00221340408978576

Fischer, G. \& Derry, S., 2005, 'Toward a model and theory for transdisciplinary graduate education', Paper presented at 2005 AERA annual meeting, Symposium, Sociotechnical design for lifelong learning: A crucial role for graduate Education, April, Montreal. 
Fransen, H., 2013, Old towns and villages of the Cape, Jonathan Ball, Cape Town.

Frodeman, R., 2010, 'Introduction', in R. Frodeman, J.T. Klein, C. Mitcham \& J.B. Holbrook (eds.), The Oxford handbook of interdisciplinarity, pp. XXVIII-XXXIX, Oxford University Press, New York.

Gehlert, S., Murray, A., Sohmer, D., McClintock, M., Conzen, S. \& Olopade, O., 2010 'The importance of transdisciplinary collaborations for understanding and resolving health disparities', Social Work in Public Health 25(3-4), 408-422. https://doi.org/10.1080/19371910903241124

Hadorn, G.H., Biber-Klemm, S., Grossenbacher-Mansuy, W., Hoffman-Riem, H., Joye, D., Pohl, C. et al., 2008, 'The emergence of transdisciplinarity as a form of research', in G.H. Hardon, H. Hoffman-Riem, S. Biber-Klemm, W. GrossenbacherMansuy, D. Joye, C. Pohl, et al. (eds.), Handbook of transdisciplinary research, pp. 19-39, Springer, Bern.

Hall, M., 2010, 'Community engagement in South African higher education', in The South African Council on Higher Education (ed.), Community engagement in South African higher education, pp. 1-52, Jacana Media, Pretoria.

Hoffman-Riem, H., Biber-Klemm, S., Grossenbacher-Mansuy, W., Hardon, G.H., Pohl, D.C., Wiesmann, U. et al., 2008, 'Idea of the handbook', in G.H. Hardon, H. Hoffman-Riem, S. Biber-Klemm, W. Grossenbacher-Mansuy, D. Joye, C. Poh et al. (eds.), Handbook of transdisciplinary research, pp. 3-17, Springer, Bern.

Klein, J.T., 2008, 'Education', in G.H. Hardon, H. Hoffman-Riem, S. Biber-Klemm W. Grossenbacher-Mansuy, D. Joye, C. Pohl, et al. (eds.), Handbook of transdisciplinary research, pp. 399-410, Springer, Bern.

Leavy, P., 2011, Essentials of transdisciplinary research: Using problem-centred methodologies, Routledge, New York

Liu, G., 1995, 'Knowledge, foundations, and discourse: Philosophical support for service-learning', Michigan Journal of Community Service-Learning 2(1), 5-18.

Martin, V., 2017, Transdisciplinarity revealed: What librarians need to know, Libraries Unlimited, Santa Barbara, CA.

McClam, S. \& Flores-Scott, E.M., 2012, 'Transdisciplinary teaching and research: What is possible in higher education?', Teaching in Higher Education 17(3), 231-243. https://doi.org/10.1080/13562517.2011.611866

McDaniels, M. \& Skogsberg, E., 2017, 'The scholars we need: Preparing transdisciplinary professionals by leveraging the scholarship of practice', New Directions for Higher Education 2017(178), 71-83. https://doi.org/10.1002/ he. 20235

Mitchell, T.D., 2008, 'Traditional vs. critical service-learning: Engaging the literature to differentiate two models', Michigan Journal of Community Service Learning 14(2), differentia.

Mouton, J. \& Wildschut, L., 2007, An impact assessment of the CHESP initiative: High-level findings, JET Education Services, Johannesburg.

Nash, J.M., 2008, 'Transdisciplinary training: Key components and prerequisites for success', American Journal of Preventative Medicine 35(S2), S133-S140. https://doi.org/10.1016/j.amepre.2008.05.004

National Planning Commission, 2012, National Development Plan 2030. Our future make it work, viewed 10 July 2017, from https://www.gov.za/sites/default/files/ NDP-2030-Our-future-make-it-work_r.pdf

Nicolescu, B., 2010, 'Methodology of transdisciplinarity - levels of reality, logic of the include middle and complexity', Transdisciplinary Journal of Engineering and Science 1(1), 19-38. https://doi.org/10.22545/2010/0009
Palmer, M., Owens, M. \& Sparks, L., 2006, 'Interdisciplinary (retail) research: The business of geography and the geography of business', Environment and Planning A: Economy and Space 38(10), 1775-1783. https://doi.org/10.1068/a3810com

Province of the Western Cape, 2014, Western Cape Land Use Planning Act, No. 3 of 2014, Provincial Gazette Extraordinary, Province of the Western Cape.

Pinfold, N., 2014a, 'Generating new knowledge with and in a community setting', paper presented at Planning Africa 2014 conference, South African Planning Institute, Durban, 19-22 October.

Pinfold, N., 2014b, 'An overview of the Flamingo Crescent community engagement and service-learning project within CPUT Department of Town and Regiona Planning', paper presented at the Association of African Planning Schools (AAPS) conference, AAPS, Cape Town, 17-19 November.

Pinfold, N., 2018, 'Communicative mapping as a means for promoting legal land tenure: The case study of the Goedverwacht Moravian Mission Village, in the Western Cape, South Africa', Town and Regional Planning 72, 1-12. https://doi. org/10.18820/2415-0495/trp72i1.1

Repko, A.E., 2008, Interdisciplinary research: Process and theory, Sage, Los Angeles, CA.

Republic of South Africa (RSA), 1987, Rural Areas Act, No. 9 of 1987, Government Gazette, Government Printers, Pretoria.

Stokols, D., Hall, K.L., Moser, R.P., Feng, A., Misra, S. \& Taylor, B.K., 2010, 'Crossdisciplinary team science initiatives: Research, training, and translation', in R. frodeman, JT Klein C. Mitcham \& J.B. Holbrook (eds.), The Oxford handbook of interdisciplinarity, pp. 471-493, Oxford University Press, New York.

Petersen, N. \& Osman, R., 2017, 'An introduction to service learning in South Africa', in R. Osman \& N. Petersen (eds.), Service learning in South Africa, pp. 1-32, Oxford University Press, Cape Town.

Polkinghorne, D., 2004, Practice and the human sciences: The case for a judgement based practice of care, State University of New York Press, Albany.

Richman, K.A., 1996, 'Epistemology, communities, and experts: A response to Goodwin Liu', Michigan Journal of Community Service Learning 3(1), 5-12.

Scheepers, J., 2014, 'An integrated curriculum model for service-learning in faculties: Design implementation and quality', Presentation (on behalf of CPUT's ServiceLearning Unit) to CPUT's Faculty of Informatics and Design, 19 June.

Thomson, A.M., Smith-Tolken, A.R., Naidoo, A.V. \& Bringle, R.G., 2011, 'Service learning and community engagement: A comparison of three national contexts', Voluntas 22(2), 214-237. https://doi.org/10.1007/s11266-010-9133-9

Tucker, R.E., 1999, 'Biting the pragmatist bullet: Why service-learning can do without epistemology', Michigan Journal of Community Service Learning 6(1), 5-14.

Van Breda, J. \& Swilling, M., 2018, 'The guiding logics and principles for designing emergent transdisciplinary research processes: learning experiences and settlement, South Africa', Sustainability Science 14, 823-841, https://doi. org/10.1007/s11625-018-0606-x

Wall, S. \& Shankar, I., 2008, 'Adventures in transdisciplinary learning', Studies in Higher Education 33(5), 551-565. https://doi.org/10.1080/03075070802373008

Woest, Y., 2018, 'Beginner teachers' experiences of transdisciplinary demands of a school curriculum', The Journal for Transdisciplinary Research in Southern Africa 14(2), 1-7. https://doi.org/10.4102/td.v14i2.488

Yoder, S.D., 2016, 'Pragmatism, pedagogy, and community service learning', Michigan Journal of Community Service Learning 22(2), 5-15. 